Kafkas Üniversitesi Sosyal Bilimler Enstitüsü Dergisi

Kafkas University Journal of the Institute of Social Sciences

Bahar Spring 2020, Sayı Number 27, 11-33

DOI:10.9775/kausbed.2021.002

Gönderim Tarihi: 24.03.2021

Kabul Tarihi: 16.05.2021

ANTIK ÇAĞ HEYKELTIRAŞLIĞINDA HEYKEL TIPLERINIIN OLUȘUMU ${ }^{1}$

\title{
The Formation of Sculpture Types in the Ancient Age Sculpture
}

\begin{abstract}
Abdulhadi DURUKAN
Dr., Atatürk Üniversitesi,

Edebiyat Fakültesi Arkeoloji Bölümü

Klasik Arkeoloji Anabilim Dalı

abdulhadidurukan@hotmail.com

ORCID ID: 0000-0001-5624-0415

$\ddot{O} z$

Çalışmanın Türü: Araştırma

Bu araştırmada Antik Çă̆ medeniyetlerinin sosyo-kültürel yapısına ışık tutan unsurlardan biri olan ve özellikle Grek etki alanının tümüne yansıyan heykel sanatı ve heykel tiplerinin oluşumunda etkin rol oynayan unsurlar ele alınmıștır. Antik Çă heykel sanatı, kronolojiye bağlı kalınarak dönemsel özellikleriyle özetle aktarıldıktan sonra çalışmanın asıl konusu olan Antik Çă̆ heykeltıraşlığında heykel tiplerinin oluşumu yani bu tiplere isim veren unsurlar farklı yönleriyle ayrintılı şekilde incelenmiştir. Arkeoloji literatüründe; buluntu yeri, yazıt, eseri yapanın ismi, bugün bulunduğu müze, koleksiyoncusu vb. durumlarla anılan tiplere bu açıdan daha önce çok bakılmaması bu makalenin önemini artırmaktadır.

Anahtar Kelimeler: Grek, Roma, Heykel, Tip, Kopya

Abstract

In this research, the elements that play an active role in the formation of sculpture art and sculpture types, which are one of the elements that shed light on the socio-cultural structure of Ancient civilizations and especially reflected in the entire Greek influence area. After the art of sculpture in the Ancient Age is summarized with its periodic features by adhering to the chronology, the formation of sculpture types in the Ancient sculpture, which is the main subject of the study, that is, the elements that give names to these types, are examined in detail. In the archaeological literatüre; the place of find, the inscription, name of the person who made the work, the museum where it is located today, its collector, etc. the fact that the types that are mentioned with these conditions have notbeen looked at from this point of view increases the importance of this article.
\end{abstract}

Keywords: Greek, Roman, Sculpture, Type, Replica-Copy

\section{GIRİŞ}

Eski çağlardan itibaren insanoğlu anlayıp kavrayamadığ doğa olaylarına karşı inandıkları güçlere ve değerlere sunular yapıp, çeşitli objeler hediye etmişlerdir. Zaman geçtikçe bu sunuların ve hediyelerin kapsamı

${ }^{1} \mathrm{Bu}$ çalışma Atatürk Üniversitesi Sosyal Bilimler Enstitüsü Arkeoloji Anabilim Dalında Doç. Dr. Ali Yalçın Tavukçu danışmanlığında 2020 yılında tamamlanan "Grek Heykeltıraşlı̆̆ında Heykel Tipleri” adlı doktora tezinden türetilmiştir. 
genişlemiş ve çeşitlilik kazanmıştır.

Geçmiş medeniyetlerin anlaşılıp değerlendirebilmesinde arkeolojik buluntuların, bu buluntular içerisinde de heykeltıraşlık eserlerinin önemi büyüktür. Heykellerin yansıttığı sanat ve üslup özellikleri; ele geçtikleri toplumların sosyo-kültürel yapılarını ve inançlarını algılayıp açıklayabilmede diğer eserler gibi önemli rol oynamaktadır.

Antik Dönem insanının sanatsal faaliyetlerini değerlendirirken, oluşturdukları nesnelerin yapılma amaçlarını anlamaya çalışmak, konuyla alakalı değerlendirmenin yarım kalmaması açısından önemlidir. Günümüzde müzelerde teşhir edilen eserlerin, yapıldıkları dönemlerde gündelik hayatta kullanıldıklarını ve hayatın bir parçası olduğunu unutmamak gerekir.

Zamanla Grek etki alanının tümüne (Harita) yansıyacak olan Grek sanatının da modern sanat anlayışından farklı olduğu anımsanmalıdır.

Çalışma kapsamında özellikle Grek heykeltıraşılık sanatına fazlaca değinilecek olması; Greklerin, sanatın birçok dalında olduğu gibi heykel sanatında da Yakın Doğu ile Mısır'dan fazlaca etkilenmeleri ve bu sanatı sonraları kendi üslup-teknikleriyle harmanlayarak ustaca geliştirmelerinden kaynaklanmaktadır. Ayrıca Antik Çağ'ın pek çok medeniyetinin özellikle heykeltıraşlıkta Grekleri örnek almaları ve benzer üslupta eser oluşturmaları Grek heykel sanatına yoğunlaşmamızı zorunlu kılan diğer önemli bir unsurdur.

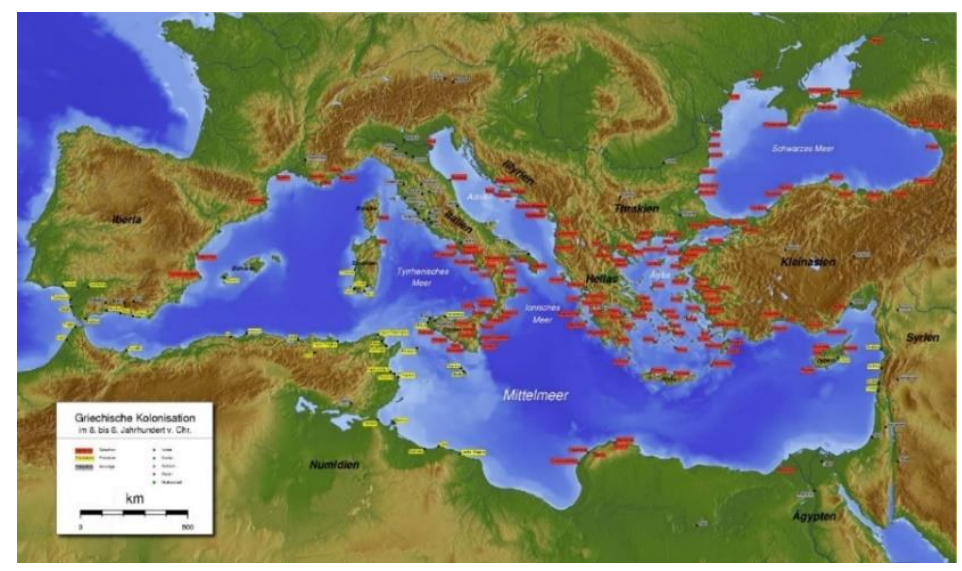

Harita. Grek Kolonizasyon Alanları - (https://ancient-greece.org/)

Sanata hak ettiği değeri veren bir kesimin henüz oluşmadığ 1 dönemlerde sanatçılar, alıcının taleplerini karşılayan kişilerdi (Boardman, 2017, s. 14). Antik Çağ heykeltıraşlık eserlerini de bu açıdan değerlendirmenin önemi büyüktür. Üzerinde durulması gereken diğer bir 
husus da özellikle insanın sanatçı tarafından nasıl ele alındığını ve eldeki malzemeyi ne şekilde işlediğini doğru biçimde analiz etme gerekliliğidir. Arkaik Dönemle beraber heykellerin ilk örneklerinde izlenen katı görünüm ve sertlik giderek yerini değişik uğraşlar içindeki insanın yaptığı işleri de konu edinmek suretiyle, anatomik özelliklerin en ufak ayrıntısına kadar gösterilebilmesine doğru gelişmiştir. Heykeltıraşlık gelişmeye devam ettikçe sanatçı, gerek tanrıların gerekse kahraman ya da sıradan insanların belirgin özelliklerini özgün bir bakış açısıyla daha çok irdelemeye ve bu düşünceyle eserlerini oluşturmaya çalışmıştır. $\mathrm{Bu}$ bağlamda heykel tiplerinin farklılaşmaya ve artmaya başladığı özellikle Klasik Dönem heykeltıraşlarıyla ilgili antik yazarlardan edinilen bilgiler bu anlamda çok kıymetlidir.

Heykel sanatına bakıldığı zaman sanatın mı dini, dinin mi sanatı oluşturduğu konusunda çokça düşünülmesi gereken bir durumun oluştuğu da görülmektedir. Çünkü her ikisi de toplum ihtiyaçları doğrultusunda doğarak gelişmiş ve sürekli birbirinin tamamlayıcısı olmuştur. Öyle ki Arkaik Dönem heykel sanatında tanrıları yüceltmek için tanrısal özelliklerde çok sayıda heykel yapılmış iken ve Klasik Dönem sanatında toplumların başarısıyla tanrilar ve insanlar aynı sahnede betimlenerek, toplumda önde gelen insanlar ön plana çıkartılmıştır. Helenistik sanat ise daha özele inerek sıradan insanı ele almış ve yaşamın merkezine tanrı ya da toplumu değil insanı oturtmuştur (Resim 1)

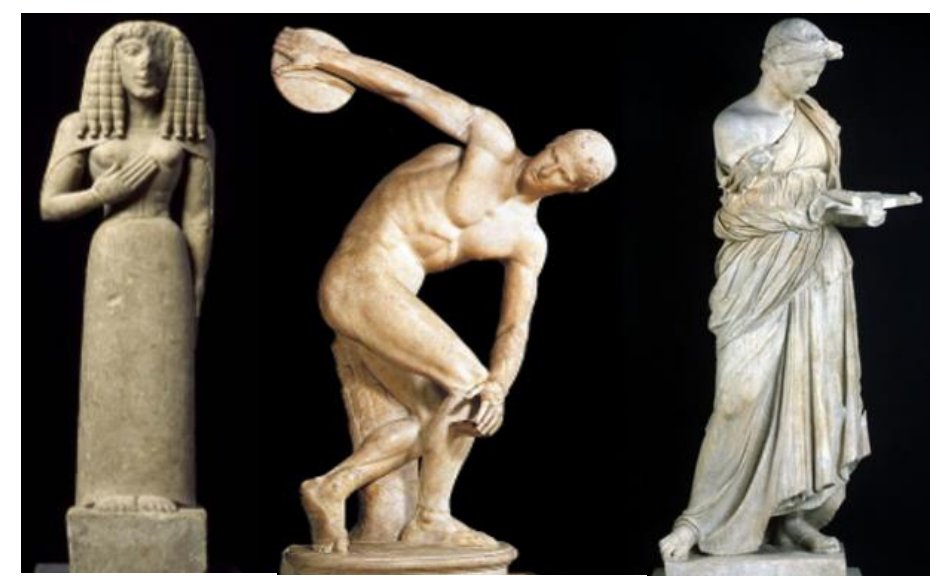

Arkaik Dönem

(MÖ 640-630)

Auxerre Tanrıçası

Paris Louvre Müzesi

M: Kireçtaş1/Y:0.65 m (https://www.louvre.fr)

\begin{abstract}
Klasik Dönem (MÖ 450 Civar1)
\end{abstract}

Discobolus

Roma Therme Müzesi M: Mermer/Y:1.55 m (https://17green.w.com)
Helenistik Dönem (MÖ 3. yüzyıl) Antiumlu Kız/Hizmetçi Roma Therme Müzesi M: Mermer/Y:1.80 m. (https://tr.pinterest.com)

Resim 1. Arkaik, Klasik ve Helenistik Dönem Örnek Eserler 


\section{ANTİK ÇĂ̆ HEYKELTIRAȘLIĞI}

Antik Çağ heykeltıraşlık eserlerinin yapıldıkları tarihten itibaren çok uzun bir zaman geçmesinden dolayı büyük bir bölümünün tahrip olup günümüze ulaşmaması doğaldır. Yine de bu tarz eserleri ana hatlarıyla tarihlendirerek gelişimleri hakkında fikir sahibi olmaya yetecek kadar eser mevcuttur (Richter, 1984, s. 39). Bunun dişında özellikle özgün Grek heykellerinin Romalı sanatçılar tarafından kopyalarının yapılması suretiyle yinelenmeleri bu heykellerin daha iyi anlaşılıp değerlendirilmeleri açısından önem arz etmektedir. Ayrıca Antik Çağ sanatı konusunda kadim bilgiler barındıran Antik Dönem yazarlarının eserleri ile tapınak listeleri, adak yazıtları, heykel ve kabartmaların tabanlarına yazılan yazıtlar, bu eserlerle alakalı bilgi sahibi olunmasını sağlayan diğer önemli unsurlardır (Richter, 1984, s. 39).

Yunanistan'da anıtsal mimarinin olduğu kadar heykel sanatının kökeni ve esin kaynağı doğuya, özellikle de Misır'a dayanmaktadır (Boardman, 1967, s. 15; Richter, 1970, s. 22). Öyle ki Grek sanatında bu dalların daha anlaşılır olmasında Mısır Medeniyeti ve sanatının incelenmesi belirleyici olmuştur. Grek heykel sanatının henüz olgunlaşmadığı zaman aralığında, Yunanlı sanatçıların Mısır heykeltıraşlığının sert ve güçlü madde kütlesine hareket ve estetik verme konusundaki başarısızlığını örnek almasını ve bundan uzun süre etkilenmesini doğal karşılamak gerekir. $\mathrm{Bu}$ durum kendisini en çok frontalitenin etkin olduğu ayakta duran çıplak erkek (=Kouros) ve giyimli kadın (=Korai) heykellerinin erken örneklerinde göstermektedir. Fakat Yunan heykeltıraşları, Mısır sanatında daha uzun bir dönem devam edecek olan bu tekdüzelikten ve dar bakış açısından kurtulmayı bilmekle beraber yaşadıkları devrin çok üstünde eserler ortaya koymayı da başarmışlardır.

Tanrı-tanrıça betimleri, kahramanların başından geçen mitolojik olaylar, sporcular, çocuk betimleri, yas tutan kadınlar ile Tanrı-Gigant savaşları ve Lapith-Kentaur mücadeleleri Grek sanatının birçok dalında olduğu gibi heykel sanatında da sıkça işlenen konular arasındadır. Toplum içinde söz sahibi olan kişilerin heykellerinin yapılması MÖ 5. yüzyılda başlamaktadır (Richter, 1984, s. 40). Ayrıca özellikle erken Yunan heykellerinin mimari ve dinle ilişkisini hem tapınaklarda kabartmalar için friz ve alınlık gibi alanların yapılması hem de tapınak alanlarında adak heykeli ve cella içlerinde kült heykellerinin bulunmasıyla açıklamak mümkündür.

Yunanlı heykeltıraşlar büyük heykeller için genellikle mermer, 
kireçtaşı, bronz, pişmiş toprak, altın-fildişi karışımı ve bazen de demir kullanmaktaydılar (Cook, 1972, s. 74). Nemden çabuk etkilenen ve çürümeye müsait ahşap eserler ne yazık ki günümüze ulaşmamıştır, (Richter, 1984, s. 40). Ahşaptan yapılan eserlerin varlı̆̆ yazılı kaynaklardan ve birkaç eserin yakın zamanda çekilmiş fotoğraflarından anlaşılmaktadır (Boardman, 2017, s. 69). Çeşitli malzemelerden yapılan eserler üslup açısından benzer bir gelişim gösterse de yapılış metotları birbirinden farklıdır. Önemli bir diğer hususta hemen hemen bütün taş heykellerin lokal yada genel olarak boyanmalarıdır (Richter, 1984, s. 40). Uçucu özelliğe sahip olmasından dolayı bu boya izlerine bugün mevcut eserler üzerinde pek fazla rastlanmamaktadir.

Yunanistan'da mimari ve heykel sanatı paralel bir gelişim izlemiştir. Yapıların, mabetlerin kıymetini artıran ve bu yapılarda belirli kısımların ön plana çıkmasını sağlayan bağımsız heykel ve kabartmalar, mimari için sadece bir süsleme aracı olmamış, içerdikleri konularla özellikle tapınakların kutsallığını artırmakla beraber bu yapılar yoluyla politik ve dini nüanslar da ihtiva etmişlerdir. Dor düzenli mimari yapılarda heykeltıraş, metop alanlarını bir veya iki figürden oluşan heykel gruplarıyla doldurmaktaydı (Boardman, 2017, s. 90). Metoplarda mücadele sahnelerinin yanı sira takip ve kovalama sahneleri de görülürken bazen hareketli sahneler bir metoptan diğerine taşabilmektedir (Blümel, 1957, s. 10). Özellikle tapınaklarda alınlık diye adlandırılan çatı altındaki üçgen alan, hem konumundan hem de yanlara doğru daralmasindan ötürü içini heykel ve kabartmalarla dolduran sanatçısını oldukça zorlayan bir kısımdır. Hal böyle iken figürler, merkezden kenarlara doğru küçülmektedir. Yatan figürler ile balık ve yılan kuyruklu yaratıklar daralan alanlarda tercih edilen betimler arasındadır (Blümel, 1957, s. 9-10).

En iyi örneklerine Atina ve çevresinde rastlanılan renkli alçak kabartmalar, genellikle mezar taşları üzerinde görülmektedir. Bazen bir sporcu bazen bir savaşçı bazen de çocuğunu tutan bir annenin betimlendiği bu kabartmalar kuroslara göre temsil ettiği kişiler hakkında daha net bilgiler sunmaktadır. Kabartmaların kendilerine yer buldukları bir diğer alan ise heykel ve stel kaideleridir (Boardman, 2017, s. 90-91).

Mezar türü yapılara işaret olması gayesiyle veya adak amaciyla oluşturulan boyalı ya da kabartmalı levha kullanma geleneğinin, Arkaik ve Klasik Grek sanatına has bir durum olmadığı, Mykenai'deki kral mezarlarında tespit edilen bulgular 1şı̆̆ında söz konusu geleneğin çok daha erken tarihlere indiği kanıtlanmıştır (Richter, 1961, s. 2; Boardman, 2001, s. 180). Özellikle adak kabartmaları Yunanistan dışındaki kültürlerde de 
bilinmekteydi. Bilhassa tapınma sahnelerindeki benzerlikler dikkat çekmektedir. Fakat kabartma sanatında (özellikle adak kabartmalarında) Yunanistan'ı diğer kültürlerden ayıran en önemli farklılık Yunanlıların gerek tanrının betimlendiği gerekse daha az öneme sahip betimlerin yer aldığ 1 bu kabartmaları büyük ölçeklere bağlı kalarak daha anıtsal boyutlarda yapmalarıdır (Boardman 2001, s. 180; Richter, 1961, s. 4). Mermer kabartmalar dışında kireç taşı, ahşap ve kilden üretilen boyalı kabartma örneklerine de rastlanılmaktadır. Bu tip kabartmaların gelişim sürecine kısaca değinecek olursak;

Geometrik Dönem'de ve 7. yüzyılda Yunanlılar, mezarları işaretlemek amacıyla doğadan olduğu gibi alınan ya da kabaca biçimlendirilen taş levhalar kullanmışlardır. Bu levhalar üzerinde herhangi bir figür izine rastlanılmamakla beraber bazılarında kazıma olarak yapılan yazılar tespit edilmiştir (Boardman, 2001, s. 180). Geç Klasik ve Helenistik Dönem başlarında mezarların ve bu mezarlar üzerindeki kabartmaların genel görünümü öncül dönemlere göre oldukça farklılaşmıştır. Üzerinde kabartma bulunan mezar taşlarının çoğu gerçek boyutlara yakın figürlerle oluşturulmuştur. Merkezde ana mezar taşı ve duvarlar ya da ön tarafinda serbest heykellerle donatılan daha özenli mezarlar ise alçak duvarlı yarım daire teraslar biçiminde tasarlanan alanlara yapılmaktaydı. Köpekler, aslanlar, sirenler, yas tutan kadınlar ve nadir olarak da diz çökmüş okçular buralarda yapilan betimler arasindadır (Boardman, 1995, s. 114-115).

Mezar taşı mahiyetindeki steller ise MÖ 400'den, aşırı harcamaların yasaklandığı MÖ 317 yılına kadar sanatsal anlamda en parlak dönemini yaşamıştır. Arkaik Dönem'den itibaren sırasıyla bitkisel motifler, ayakta duran genç erkek figürleri, sporcu figürleri, köpekli adam tasvirleri; biraz daha geç tarihlere doğru ayakta duran genç kız figürleri, elinde bazı nesneler (horoz, yağ şişesi vb.) taşıyan çocuk betimleri çokça tercih edilen konular arasindadir (Boardman, 2001, s. 181-182).

Adak stellerinde de erken dönemlerde görülen oturan kadın ve erkek tasvirleri (Richter, 1961, s. 2-3), Geç Arkaik Dönem'de yerini tapınan kişi tasvirlerine, Dioskurlar'a; Klasik Dönem ve daha geç tarihlerde ise ziyafet (ölü yemeği=totenmahl) anında tasvir edilen kahraman figürlerine (Fabricius, 1999, s. 21), araba tasvirlerine, kutlama sahnelerine ve tanrıça tasvirlerine bırakmıştır (Boardman, 2001, s. 184-185). Özellikle Arkaik Dönem Grek heykeltıraşları, stellere dekoratif amaçlı boyamalar yapmışlardır. Mavi, kırmızı, siyah, beyaz ve nadiren yeşil bu boyamalarda kullanılan renkler arasındadır (Richter, 1961, s. 6). 
Klasik Dönem sonlarına kadar sahip oldukları önemi, Helenistik Dönem'de kısmen yitiren kabartmalar biçim ve işlev yönünden bu dönemde pek az değişikliğe uğramıştır (Smith, 2013, s. 185). Heykeltıraşların mevcut üsluba bağlılıkları ve figür hareketliliğindeki aşina olunan durum eserlerin analizinde kolaylık sağlamaktadır (Havelock, 1964, s. 43-58).

Ayrıca Klasik Dönem tapınaklarında genellikle zeminden oldukça yükseğe yapılan ve bundan dolayı yeterince görülüp anlaşılmayan mimari heykeltıraşlık eserleri (bağımsız heykel ve kabartmalar), Helenistik Dönem sanatçıları tarafından gerek yapıldıkları yerler açısından gerekse bu eserlerin yapı bezemesinin bir parçası haline getirilmesinden dolayı daha anlaşılır bir hal almıştır, (Smith, 2013, s. 185).

Mezar ve tapınaklardaki süsleme öğeleri MÖ 3 ve 2 . yüzyıllarda dengeli bir şekilde devam ederken (Richter, 1984, s. 140), çevresi sütunlu anitsal nitelikteki sunaklar Helenistik Dönem yeniliği olarak kabul edilmektedir (Smith, 2013, s. 185).

Helenistik Dönem'le ortaya çıkan ve büyük gelişim gösteren diğer bir heykeltıraşlık faaliyeti de politik amaçlı yapılan kişiye özgü portreciliktir (Pollitt, 1990, s. 57 vd; Ridgway, 2001, s. 7-8). Günümüz modern batı sanatının önemli bir dalı olan betimleme-portre sanatı temellerinin Antik Dönem Grek sanatında atıldı̆̆ 1 genel bir kanıdır. Bu eserlerin başlangıcını oluşturan kral ve imparator betimlemeleri, MÖ 4. yüzyılın sonlarında Makedon Kralı II. Phillip ve oğlu Büyük İskender'in gerçeğe yakın tasvir edilmesiyle başlamaktadır. Bu tarihten önce de portre denemeleri olmuşsa da bunlar gerçeklikten uzaktı ve donuk ifadelerle oluşturulan eserler idealize edilmiş yüz ifadelerine sahiptiler (Gombrich, 1999, s. 106).

Hatta daha da erken tarihlerde Misır'da ve yer yer Yakın Doğu'da yaşayan birinden veya bir ölüden kalıp almak suretiyle gerçekçi portreler yapılmaktaydı ve bunlar zaman zaman taş heykellere de uyarlanmaktaydı. Yunanistan'da icra edilen İskender portreleri Roma Cumhuriyet ve İmparatorluk Dönemleri'nde de çok sayıda replika ve orijinal portre şeklinde devam ettirilmiştir (Özgan, 2013, s. 17-18).

\section{ANTIKK ÇAĞ HEYKELTIRAŞLIĞINDA HEYKEL TIPLERININ OLUŞUMU (Heykel Tiplerine İsim Veren Unsurlar)}

Çalışmanın asıl konusunu oluşturan Antik Çağ heykel tiplerine isim veren unsurların; yazıt (varsa eser üzerindeki açıklama), yapanın ismi, buluntu yeri, bugün bulunduğu müze, figürün sıfatı, figürün eylemi, eserin hangi şehir için yapıldığı (özdeşleştiği bölge ya da şehir), orijinal bir eserin 
Roma Dönemi'nde oluşturulan kopyası, koleksiyoncusu, müzeye kazandıranın ismi (nadiren) ve eserin restorasyonunu ya da çizimini yapan kişinin ismi (nadiren) olduğu gözlenmiştir. $\mathrm{Bu}$ faktörlerle Arkeoloji literatürüne geçen Grek heykel tipleri, konuyla ilgilenen bilim insanlarınca hala bu isimlerle anılmakta ve değerlendirilmektedir.

3.1. Eser Üzerindeki Yazıt (Varsa Eserler Üzerindeki Açıklayıcı Bilgiler): Geometrik Dönem'in sonlarına doğru başlayıp sonraki bazı eserlerde de devam ettirilen figürler ya da figürlere ait kaideler üzerindeki yazı geleneği sunuyu gerçekleştiren kişi, sununun yapıldığı tanrı ya da tanrıça ve bazen de eseri yapan sanatçı hakkında farklı detaylar yansitmaktadir.

3.1.a: (Resim 2) Tanrı Apollon'a ait ilk örneklerden birisi olan ve Thebes (Tebai)'ten ele geçmiş, Erken 7. yüzyıl tarihli bronz heykelciğin bacak kısmında "Mantiklos beni gümüş oklu tanrlya sundu. Phoibos dönüşte bana güzel bir iyilik yap" yazmaktadır (Karaosmanoğlu, 2005, s. 63). Üzerindeki yazıttan anlaşılacağı üzere Mantiklos tarafından adanan ve 'Mantiklos Apollonu' (Lullies, 1956, s. 35-36; Fuchs, 1969, s. 21-22; LIMC, 1984, s. 194) olarak adlandırılan $20 \mathrm{~cm}$ yüksekliğe sahip eserde ayakta betimlenen tanrının sol elinde büyük olasılıkla gümüş yay bulunmaktaydı. Ayrıca şimdi boş olan göz oyuklarına değerli taşlar konulmuş olmalı (Karaosmanoğlu, 2005, s. 63).

3.1.b: (Resim 3) Kaidesindeki yazıttan dolay1 kopya eserler arasında, hakkında net bilgiler edinilen bir heykel olması açısından özel bir konuma sahip olan 'Troas Aphroditesi' oldukça önemlidir. Yazıtta "Menophantos bu heykeli Troas'ta bulunan Aphrodite'den yapmıştır" ibaresi bulunmaktadır (LIMC, 1984, s. 53-54; Smith, 2013, s. 82).

Bu kopya esere model olan Troas'taki Aphrodite kuşkusuz bir kült heykeli olmakla birlikte büyük olasılıkla Erken Helenistik Dönem eseriydi (Smith, 2013, s. 82). Tanrıça betimi Capitolini (Charbonneaux, 1943, s. 40; Bol, 1981, s. 145) ve Medici Aphroditeleriyle (Havelock, 1995, s. 93) büyük benzerlikler gösterirken farklı olarak tanrıça sol eliyle yanında duran giysi (ya da havlu) parçasını edep yerine doğru çekmektedir. Kopya eserin orijinali MÖ 3-2. yüzyıla tarihlenmektedir (Smith, 2013, s. 82). 


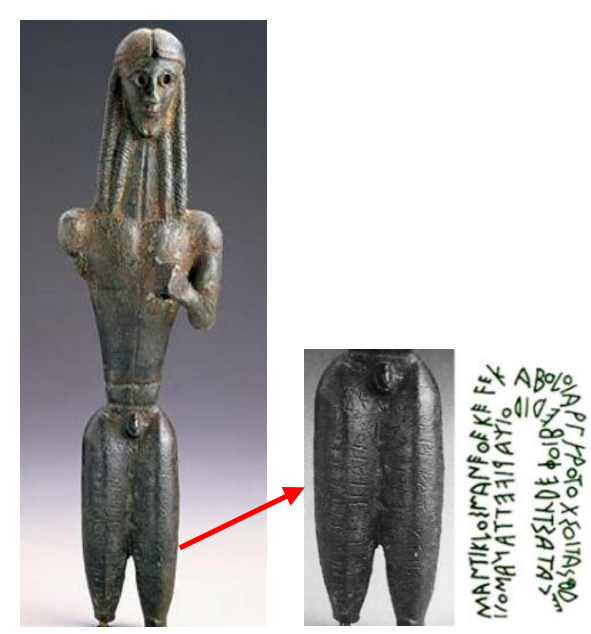

Resim 2. Mantiklos Apollonu Boston Müzesi

Mal: Bronz / Yük: 0.25 m. (https://gramho.com)

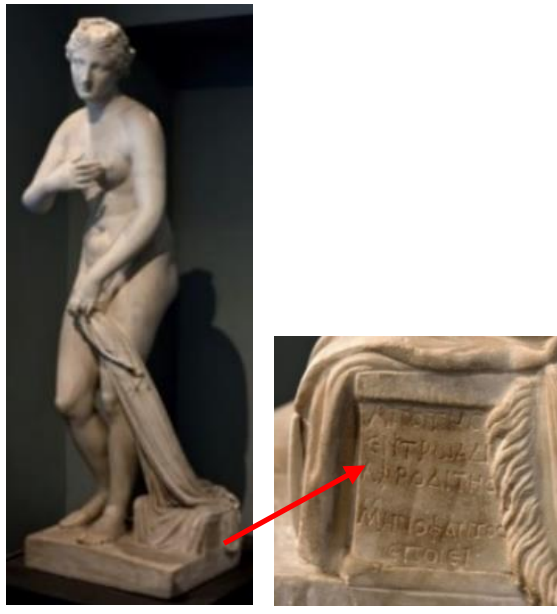

Resim 3. Troas Aphroditesi Roma Therme Müzesi

Mal: Mermer / Yük: 1.87 m. (https://tr.pinterest.com)

3.2. Eseri Yapanın İsmi: Eserler üzerinde bulunan yazıtlardan sonra önem sırasına göre eseri yapanın ismiyle arkeoloji literatürüne geçen ve tarafımızca tip olarak değerlendirilen yapıtların da sayısı oldukça fazladır.

3.2.a: (Resim 4) Çömlekçi Nearkhos'un adadığı, heykeltıraş Antenor'un yaptığı ve heykeltıraşının ismiyle anılan 'Antenor Koresi' Geç Arkaik Dönem'in önemli özellikler yansıtan eserlerindendir (MÖ 530-520) (Alscher, 1961, s. 51-55). Boardman'1n anitsal boyutlardaki Attika örneklerinin sonuncusu diye tanımladığı eserde, yüz hatlarının erkeksi ifadeye sahip olduğu belirtilmiştir (Boardman, 2001, s. 95,138). Atina Akropolisi'nde bulunan eserin üzerinde giysi olarak khiton üzerinde himation bulunmaktadır. Himation, dirsekten kırılarak öne doğru uzatılan sağ koldan aşağ 1 dökümlü bir şekilde bırakılmıştır. Hem kolun vücuttan ayrılması, hem de koldan aşağı dökülen mantonun plastik kıvrımları stil kritik açısından göz önünde bulundurulması gereken özellikler arasında yer almaktadır. Ayrıca sol bacağın hafif öne doğru atılmasıyla oluşan kıvrım yapıs1 ve hareketten dolayı bacağın belli olması, eserin dönemi düşünüldüğünde vurgulanmadan geçilmeyecek hususlar arasındadır.

3.2.b: (Resim 5) Atina Akropolisi'nde ele geçmiş ve MÖ yaklaşı 480 civarına tarihlenen 'Kritios Genci' (Oğlanı), Klasik Dönem'in ve bu dönemle oluşan yeni akımın ilk örnekleri arasındadır (Başaran \& Kasapoğlu, 
2018, s. 2835-2853). Arkaik Dönem'in son kuroslarından olan ve MÖ 510500'lere tarihlendirilen, frontal duruşun hala izlendiği 'Aristodikos Kurosu'nun (Alscher, 1961, s. 78-79) aksine bu eserde (Kritios Oğlanı) vücut ağırlığının bir ayağa verilip diğer ayağın oldukça serbest bırakılmasıyla kalça aşağı doğru çekilmiş, omuz ve baş kısmı da hafifçe bir yana kaykılmıştır. Bu heykel, Arkaik Dönem'in en önemli eserlerinden biri olarak kabul görmüş Tyran Öldürenler'deki Genç Harmodios'a (Bol, 1981, s. 33) çok benzediği için eserin heykeltıraşı Kritios'a atfedilerek (Lullies, 1956, s. 53) (heykeltıraşın diğer eserlerindeki benzer duruş ve üslup özellikleri de göz önünde bulundurularak) bu isimle anılmıştır.

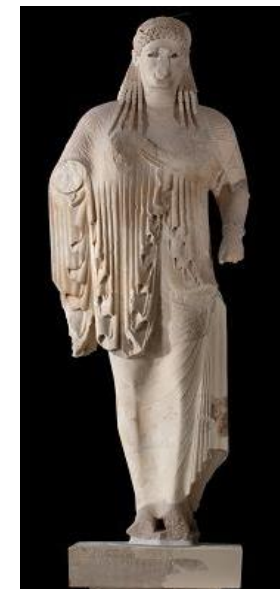

Resim 4. Antenor Koresi Atina Akropolis Müzesi

Mal: Mermer / Yük: 2.15 m. (https://www.pinterest.cl)

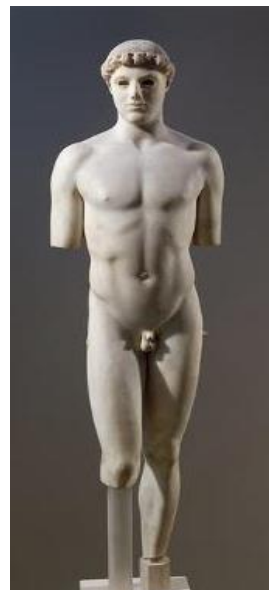

Resim 5. Kritios Oğlanı Atina Akropolis Müzesi Mal: Mermer / Yük: $0.86 \mathrm{~m}$. (https://www.art.com)

3.3. Eserin Buluntu Yeri: Grek heykeltıraşlı̆̆ında heykel tiplerine isim veren diğer bir unsur da eserlerin buluntu yerleridir.

3.3.a: (Resim 6) Erken Klasik Dönem'in ilk büyük boyutlu bronz heykeli olan ve Delphi'deki kutsal yol üzerinde bulunan 'Delphi Arabacısı' (Lullies, 1956, s. 54-55) buluntu yeriyle adlandırılmıştır. MÖ 478 ya da 474'te kazanılan bir yarış şerefine dikildiği tahmin edilen (Alscher, 1961, s. 192), yumurta biçimli baş formu ve sı̆g lüleleriyle hala Arkaik özellikler taşıyan eser üzerinde arabacıların çokça tercih ettiği khiton türü kıyafet izlenmektedir. Başın hafif sağa dönmesi, figürün genel olarak bükülme hareketinde olması ve ayakların çok güzel işlenmesi, kalıp şeklinde aşağı sarkan uzun eteğin yalın görüntüsünün önüne geçmiştir. Ayrıca heykelin yüz 
ifadesi yapılan eyleme göre Arkaik Dönem kuroslarını hatırlatırcasına sakin ve durağan olsa da özellikle atın koşumlarını tutan kolun kaslarıyla hareket halindeki yarış arabasında dengede kalmak için ayaklara kazandırılan duruş şekli gibi özellikleriyle gerçekçiliğe doğru kaydedilen ilerleme hissedilmektedir.

3.3.b: (Resim 7) Genç kızlarla, kadınlarla ve kadınların doğurganlık gibi biyolojik durumlarıyla da ilişkilendirilen Tanrıça Artemis'in av meraklısı vahşi bir genç kız değil de düzgün vücutlu bir kadın olarak betimlendiği 'Piraeus Artemis'i oldukça önemli bir eserdir (LIMC, 1984, s. 638; Ridgway, 1990, s. 363). Pire'de 1959 y1lında sondaj yapan işçilerce görülüp sonrasında hassas bir çalışmayla gün yüzüne çıkarılmıştır (Ridgway, 1990, s. 363). Sol kol bir nesne tutar gibi yanda aşağ 1 doğru dururken sağ kol dirsekten kırılarak yukarı ve ileri doğru yönlendirilmiştir. Kavun dilimi saç üslubuyla (=melon coiffure) izlenen Artemis heykelinde sağ bacak vücut ağırlığını taşırken sol bacak dizden hafif kırılmak suretiyle geriye doğru uzatılmıştır. Bu hareketten dolayı sol ayak etek altından sağ ayağa nazaran daha çok görülmektedir. Klasik Dönem tarzında ifadesiz yüze sahip heykelin göğüs kısmında bulunan çapraz askılar sırtında olması muhtemel sadağa işaret etmektedir. MÖ. 340-330'lara tarihlendirilen eser, tüm bu özellikleriyle Polykleitos'a atfedilmektedir (Boardman, 1995, s. 82).

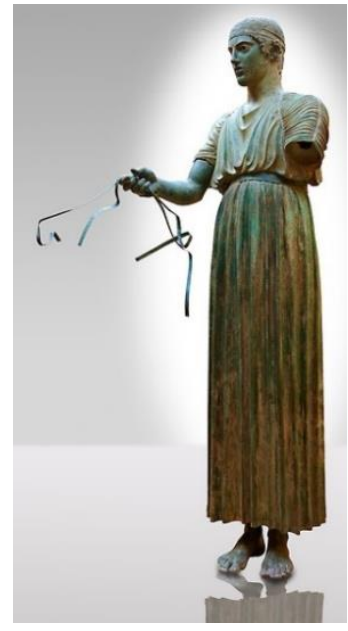

Resim 6. Delphi Arabacis1 Delphi Müzesi

Mal: Bronz / Yük: $1.80 \mathrm{~m}$. (https://funkystock.photoshelter.com)

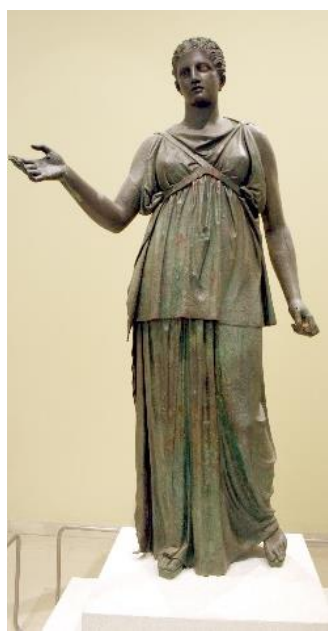

Resim 7. Piraeus Artemisi Pire Arkeoloji Müzesi

Mal: Bronz / Yük: 1.95 m. (https://en.wikipedia.org) 
3.4. Eserde Betimi Yapılan Figürün Sıfatı: Grek tanrılarına birçok farklı bölgede tapınılması onlara muhtelif sıfatların verilmesine neden olmuştur. Bir tanrı ya da tanrıçanın birden fazla sıfatı bulunabilmektedir. Literatüre bu sifatlarla geçmiş birbirinden önemli eserler mevcuttur.

3.4.a: (Resim 8) MÖ 7. yüzy1lın ortalarından itibaren Tanrıça Athena'nın 'Polias' (=şehrin koruyucu tanrıçası), 'Pallas' (=mızrak atan) ve 'Promachos' (=önde savaşan) sıfatlarıyla icra edilmiş eserleri bilinmektedir (Karaosmanoğlu, 2005: 79). Atina Akropolisi'nden oldukça sağlam ele geçmiş ve MÖ 480 civarına tarihlenen tunç döküm eserde (Fuchs, 1969, s. 177) Athena Promachos vasıfları çok net izlenebilmektedir. Başında miğferi, göğsünde aigis bulunan ve uzun giysisiyle izlenen tanrıça, bir adımını ileri atarak sağ elindeki mızrağı firlatırken tasvir edilmiştir.

3.4.b: (Resim 9) Tanrı Hermes, çobanların yolunu şaşırtan, anlaşılmaz, kurnaz bir tanrı olsa da çobanların koruyucusu Hermes yönü de bilinmektedir. Keskin görüşlü Çoban Hermes sıfatıyla bütün çobanların bu yöndeki meziyetleri de vurgulanmıştır. Hermes'in çobanlığıyla ve sürülerle olan özelliği çok sayıda terrakotta figürin ve heykelcik örneği bulunan 'Koç Taşıyan Hermes'le (Koç Taşıyan Hermes Tipi) ifade edilmiştir. Tanrının bu sıfatıyla betimlendiği eserler arasında Boston'dan MÖ 520'lere tarihlenen (Fuchs, 1969, s. 42; Richter, 1984, s. 158) Hermes Kriophoros bronz heykelciğinde tanrı; gölgelikli şapkası, kısa tuniği ve kanatlı ayakkabılarıyla, sol elinde bir koç tutmaktadır.

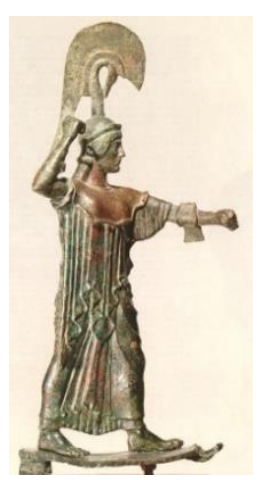

Resim 8. Athena Promachos Atina Ulusal Müzesi Mal: Bronz / Yük: 0.37 m. (https://www.pinterest.de)

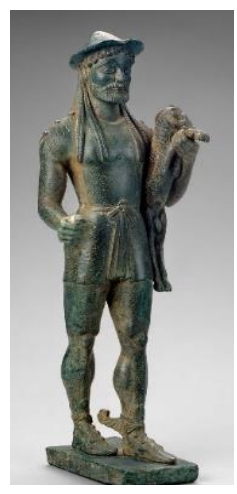

Resim 9. Hermes Kriophoros Boston Müzesi Mal: Bronz / Yük: 0.25 m. (https://www.tumblr.com/) 
3.5. Eserin Bugün Bulunduğu (Sergilendiği) Müze: Tiplere isim veren nedenler arasında buluntu yeri, yapanın ismi, figürün sıfatı kadar önem arz eden diğer bir unsur da eserlerin bugün bulundukları müzelerdir. $\mathrm{Bu}$ yolla birçok heykel tip kategorisinde değerlendirilmiş ve literatüre bu şekilde geçmiştir.

3.5.a: (Resim 10) Kaynaklarda 'Dreste Zeus'u ya da 'Dresden Zeus' tipi olarak geçen ve Roma Dönemi mermer kopyalarıyla bilinen eser (Ridgway, 1970, s. 20-21; LIMC, 1997, s. 433), tanrının asasıyla ayakta betimlendiği önemli bir yapıttır.

Özenilerek işlenen saç sakal yapısıyla olgun bir görünüm sergileyen tanrının üzerinde sağ omuzu ve kolu açıkta bırakan himation ayaklarında ise sandalet bulunmaktadır. Tanrı ve tanrıçaların farklı özelliklerinin yansıtılmaya başlandığı Klasik Döneme ait ( MÖ 440 civarı) olan eser Dresden Müzesi'nde bulunduğundan bu isimle anılmakta ve tüm bu özellikleriyle heykeltıraş Phidias'a atfedilmektedir (Richter, 1970, s. 231; Ridgway, 1970, s. 21).

3.5.b: (Resim 11) Mevsimleri getirmek, yaşamı devam ettirecek armağanları insanlığa sunmak gibi vasıfları olan Tanrıça Demeter'in heykeltıraşlık eserlerinde tek başına izlendiği yontuları genelde peplophoros kadın tipini anımsatmaktadır (Fuchs, 1969, s. 194).

Tanrıçanın klasik özelliklerde peplophoros tipiyle betimlendiği en önemli eserlerden biri MÖ 460-450 yıllarına tarihlenen orijinal bir eserin kopyası olan ve adını Cezayir'de bulunan Cherchel Müzesi'nden alan 'Demeter Cherchel' dir (Richter, 1970, s. 231; LIMC, 1988, s. 852).

Başörtülü anaç bir yapıda oluşturulmuş tanrıçanın bu görüntüsüyle kopyaları yapılmak suretiyle çok kez yinelenmesi eseri oldukça önemli kılmaktadır. Özellikle giysi kıvrım yapısıyla Athena Parthenon Tapınağ 1 üslubuna (Richter, 1970, s. 64) gidişi gösteren ve heykeltıraşının Phidias olduğu düşünülen Demeter Cherchel heykelinde kollar omuzlardan itibaren eksiktir. 


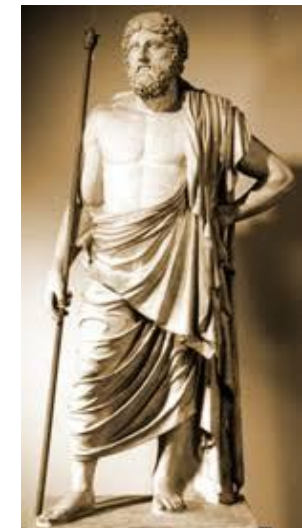

Resim 10. Dresden Zeus'u Dresden Müzesi

Mal: Mermer /Yük: 1.95 m. (https://www.beazley.ox.ac.uk/)

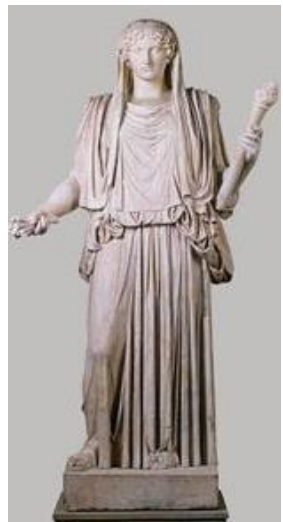

Resim 11. Demeter Cherchel Cherchel Müzesi

Mal: Mermer / Yük: $2.10 \mathrm{~m}$. (https://tr.pinterest.com/)

3.6. Eserde Tasviri Yapılan Figürün Eylemi: Bu özellikler dışında figürlerin eylemleriyle isimlendirilen tipler de sayıca fazla olmakla beraber yapıldıkları dönemlerin üslup özelliklerini yansıtmaları açısından büyük öneme sahiptirler.

3.6.a: (Resim 12) İlk bakışta bir hayvan postu üzerine uzanmış uyuyan genç bir erkek gibi görülen ama kulak detayları ve üzerine oturduğu hayvan postuyla Satyr olduğu anlaşılan 'Uyuyan Satyr Heykeli' (Barberini Faunu), (Bol, 1981, s. 145; Biers, 1987, s. 296) yaratığı eylemiyle betimleyen en ünlü heykellerden birisi olmakla beraber onun insana yakın özelliklerde oluşturulmaya çalışılan en üst düzey eserdir. Mitolojideki yaşam alanına uygun kayalık bir yerde yatar vaziyette izlenen Satyr, sarhoş olup uykuya dalmış olarak düşünülebilir. Yanlış fikirler uyandıran pozuna rağmen gerek sanatsal bir şekilde ele alınışı gerekse üst düzey bir üslupla oluşturulan barok kaslar ve genel anatomi yapısı onu çarpıcı ve ciddi bir eser haline getirmiştir. Sağ bacak ve sol kolun restore edildiği Münih kopyasının orijinalinin MÖ 200 civarına ait olabileceği düşünülmektedir (Smith, 2013, s. 139).

3.6.b: (Resim 13) Tanrı Asklepios tarafından iyileştirilen bir çocuğun ailesi tarafından şükranlarının bir göstergesi olarak adandığ düşünülen 'Bir Kazı Boğazlayan Çocuk' heykeli (Stewart, 2014, s. 277), günlük hayattan alınmış bir konu gibi görünmekle beraber literatüre de aynen çocuğun yaptığı eylemle geçmiştir (The Boy Strangling the Goose) (Ridgway, 2006, s. 643-648). MÖ 3. yüzyılın sonlarında yapıldığı tahmin 
edilen (Stewart, 2014, s. 277) orijinalin Munchen ve Louvre Müzeleri'ndeki iyi korunagelmiş kopyalarında (Stewart, 2014, s. 277) dört beş yaşlarında kilolu ve sevimli bir erkek çocuğunun boyun ve göğüs kısmından yakaladığ bir kazın boğazını sıkması işlenmiştir. Çocuğun eylemiyle birlikte boğazı sıkılan hayvanın gagasının açılması ve dilinin aldığı şekil gibi detaylar ihmal edilmemiştir.

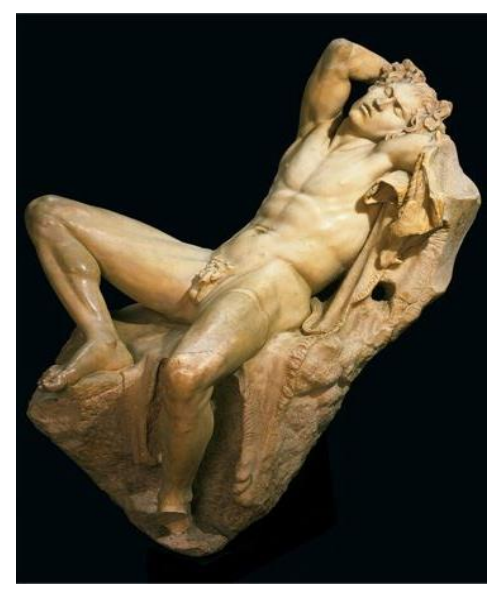

Resim 12. Uyuyan Satyr (Barberini Faunu) Munchen Glyptothek Müzesi Mal: Mermer / Yük: 2.15 m. (https://tr.pinterest.com/)

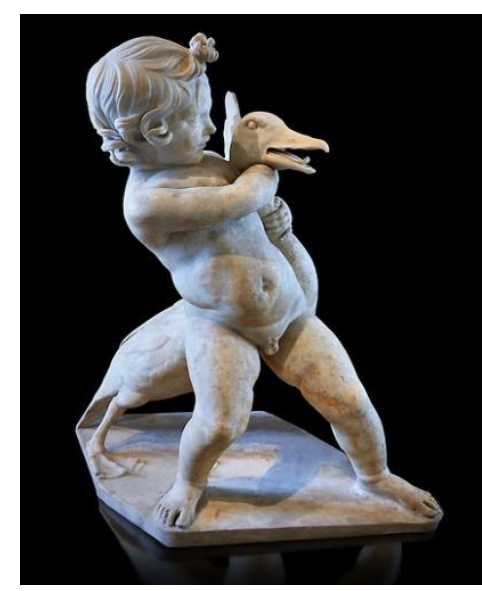

Resim 13. Bir Kazı Boğazlayan Çocuk

Paris Louvre Müzesi

Mal: Mermer / Yük: $0.92 \mathrm{~m}$. (https://funkystock.photosh.com/)

3.7. Eserin Yapıldığı Kentle Özdeşleşmesi: Doğu kültürlerinden etkilenilerek uygulanan şehirlerin personifike yani kişileştirilerek sanatta temsil edilmeleri Helenistik Dönem'de oldukça yaygınlaşmıştır. Bu tipte personifikasyonlar çok sayıda eserin bu isimlerle adlandırılmalarına ve tanınmalarına neden olmuştur. Şehirlere dair bu şahıslandırmalar, başlarında şehri temsil eden sur duvarları ve kale burçları içeren taçları bulunan Tykhelerle ifade edilmiştir.

3.7.a: (Resim 14) Helenistik Dönem'in erken safhalarına ait bahsi geçen bu tipteki eserlerin üslubunu yansıtan ve çok sayıda kopyası bulunan 'Antiokheia Tykhe'si Antakya şehrinin tanriçası olarak yapılmıştır (Ridgway, 1990, s. 233). Antiokheia kentinin kuruluş yıllarına (MÖ 300 veya hemen sonrası) tarihlenen eserin kaybolmuş orijinali muhtemelen kolossal boyutlarda ve bronz malzemedendir (Rumpf, 1949, s. 104; LIMC, 1981, s. 841 vd). Oldukça iyi korunmuş Vatikan kopyasında şehrin yamacına 
kurulduğu Sipholos Dağını temsil eden bir kaya üzerine oturan tanrıçanın başında Antakya'nın konumunu gösteren sur duvarlarının betimlendiği başlık bulunmaktadır. Bacaklarını birbiri üzerine atmış vaziyette ve başını sol omuzu üzerine hafifçe döndürmüş tanrıçanın oturduğu kayanın hemen altında Orontes yani bugünkü ismiyle Asi Irmağı'nı temsil eden genç bir erkek betimi bulunmaktadır. Gerek uzuvların işlenişi gerekse belli oranda paralellik gösteren giysi kıvrımlarıyla başarılı bir derinliğin oluşturulduğu eserde tanrıça sağ eliyle bölgenin verimli ve zengin olduğunu gösteren buğday başağ tutmaktadır.

3.7.b: (Resim 15) Yapıldığ1 ya da özdeşleştiği şehirle ismini alan bir diğer önemli eser, Helenistik Dönem denildiğinde akıllara gelen yapıtlardan biri olan ve MÖ 190 civarına tarihlendirilen 'Samothrake Nikesi'dir (Mark, 1998, s. 157-165). Geleneksel bir figür olan Nikelere ait heykeller genellikle savaş ve zafer anıtı olarak kullanılmışlardır. Rodoslular tarafindan Seleukoslular'a karşı kazanılan zaferin anısına tanrıça Nike'ye şükran duygulariyla Samothrake (Semadirek) Adası'nda adanan eserde (Stewart, 1990, s. 215), bir gemi pruvasına yüzü denize dönük olarak yerleştirilen heykelde, sağ ayağıyla bir adım atarak geminin güvertesine hafifçe basar şekilde betimlenen tanrıçanın rüzgârda dalgalanan kırık hatlar biçiminde eksenlere sahip giysisi esere büyük bir görkem ve canlılık kazandırmıştır.

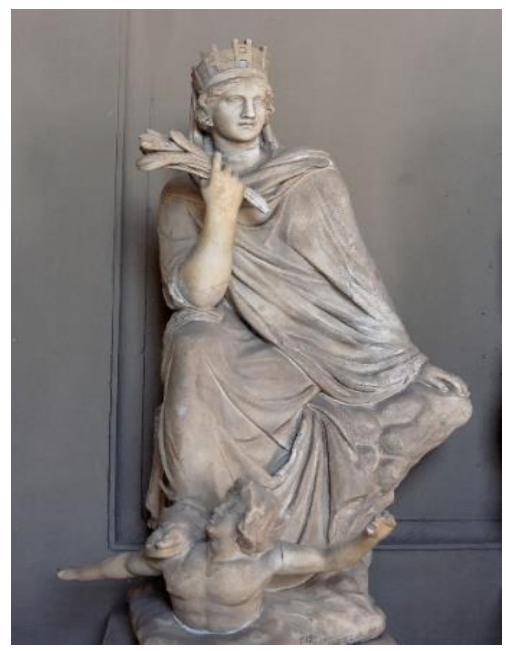

Resim 14. Antiokheia Tykhe'si Vatikan Müzesi

Mal: Mermer / Yük: 0.89 m. (https://tr.m.wikipedia.org/)

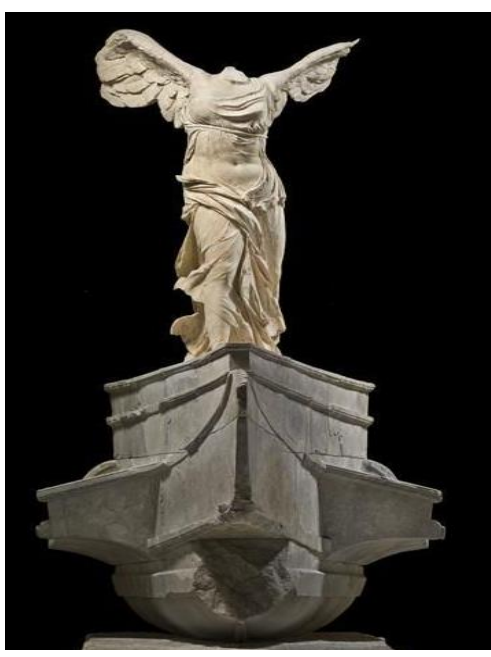

Resim 15. Samothrake Nike'si Paris Louvre Müzesi

Mal: Mermer / Yük: 2.45 m. (https://tr.pinterest.com/) 
3.8. Roma Dönemi'nde Yapılan Kopyalarıyla Adlandırılmaları: Çalışma kapsamımız her ne kadar Grek heykeltıraşlığı olsa da Yunanlı sanatçıların oluşturduğu pek çok orijinal eserin Roma Dönemi sanatçıları tarafindan sıklıkla kopyalarının yapılması bu eserleri de belli oranda incelememizi zorunlu k1lmıştır. Günümüze ulaşmayan orijinal eserler hakkında kıymetli bilgiler barındıran bu kopya eserler büyük öneme sahiptir.

Olympos'un 12 tanrı ve tanrıçası Roma Dönemi'nde isimleri değişikliğe uğratılarak tapınım görmeye devam etmiştir. Dolayısıyla bu da belli bir isimle bilinen Yunan eserinin Roma Dönemi'nde oluşturulmuş kopyasının farklı isimle anılmasına neden olmuştur.

3.8.a: (Resim 16) Aphrodite'ye, Roma Dönemi'nde Venüs olarak tapınılmıştır. Roma Dönemi'nde oluşturulan ve birçok kaynakta 'Venüs Genetrix' (Charbonneaux, 1943, s. 40; LIMC, 1997, s. 198) diye geçen eser esasen tanrıçanın çıplak tasvirlerine adım adım gidişteki en önemli betimlerinden sayılan ve orijinali MÖ 410 civarına tarihlenen 'Aphrodite Frejus'un kopyasidır (Fuchs, 1969, s. 207; Boardman, 2013, s. 219).

Vücudun genelindeki hareket zenginliği ve en önemlisi sol göğsü açıkta bırakan kıyafet detayıyla tanrıçanın cinsellikle ilişkilendirilen yönünü daha fazla ortaya çıkaran Aphrodite Frejus tipi, başlı başına bir tip olarak değerlendirdiğimiz Venüs Genetrix dişında Helenistik ve Roma Dönemleri'nde gösterişli kadın portrelerine, terrakotta figürinlerine (Tavukçu, 1999, s. 92) ve kabartmalı kâselere (Metin, 2013, s. 239-252) model teşkil eden bir tip olmuştur.

3.8.b: (Resim 17) Bu başlık altında ikinci örneğimizi Roma Dönemi'nde ismi 'Milo Venüs'üne dönüşen 'Melos Aphroditesi' oluşturmaktadır. Antik Yunan heykel sanatının en ünlü yapitlarından olan Melos Aphroditesi (Milo Venüs'ü) (Havelock, 1995, s. 93; Kousser, 2008, s. 29-30) durağan bir görüntüye sahip olsa da gövdenin çeşitli uzuvlarına verilmiş ayrı yönler ve giysi kıvrımlarındaki güçlü karşıtlıklar heykele belli oranda bir devinim kazandırmıştır.

XVIII Louis tarafindan Fransa'ya kazandırılan ve hala Louvre Müzesi'nde sergilenen MÖ 2. yüzy1l tarihli eserin omuzundan itibaren sol kolu, dirseğe yakın bir yerden itibaren de sağ kolu eksiktir. Bieber'e göre bu tip, Roma Dönemi'nde çoğunlukla bir khiton ve kanat yapısı eklenerek Nike’ye dönüştürülmüştür (Bieber, 1955, s. 160). 


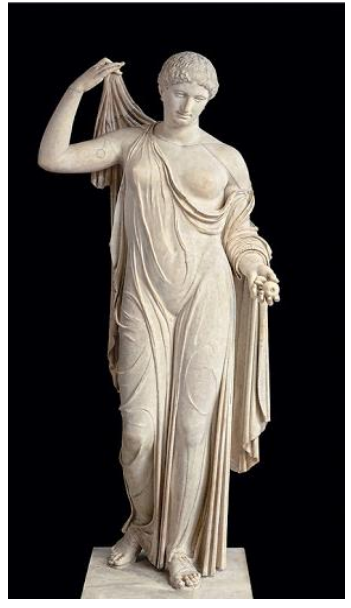

Resim 16. Aphrodite Frejus

(Venüs Genetrix)

Paris Louvre Müzesi

Mal: Mermer / Yük: $1.65 \mathrm{~m}$. (http://www.revendeurs.rmngp.fr/)

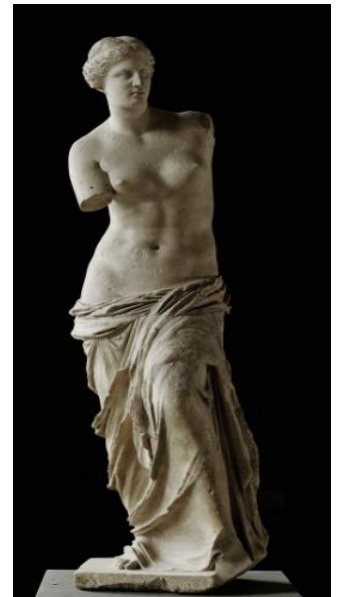

Resim 17. Melos Aphrodite'si (Milo Venüs'ü) Paris Louvre Müzesi Mal: Mermer / Yük: $1.65 \mathrm{~m}$. (https://culturacolectiva.com/)

3.9. Eserin Koleksiyoncusu: Yapıldıkları dönemler hakkında önemli bilgiler barındıran bazı eserler özellikle 19. yüzyılda zengin ailelerin koleksiyonlarını süslemekteydi. Bu eserler zamanla müzelere kazandırılarak buralarda teşhir edilmeye başlanmıştır. Birçok heykeltıraşlık eseri bugün hala koleksiyoncusunun ismiyle anılmaktadır.

3.9.a: (Resim 18) Bir elinde asa diğerinde phialeyle betimlenen 'Hera Campana', tanrıçanın çokça tekrarlanan önemli bir tipidir (Sarti, 2012, s. 5). Bu tipi tanrıçanın diğer tiplerinden ayıran en önemli özelliği ise giysinin bir kısmıyla başın örtülmüş olmasıdır. Sol bacağın hafif öne ve yana açılmasından dolayı vücut ağırlığının verildiği sol bacak üzerinde alta doğru derinlik kazanan zengin giysi kıvrımları oluşmuştur. Adını, günümüzde sergilendiği Paris Louvre Müzesi’ne getirilmeden önce 19. yüzyılın ünlü antik eser koleksiyoncusu Marquis Giovanni Pietro Campana'nın (Benucci \& Sarti, 2001, s. 15-24) koleksiyonunda bulunmasından alan eser, özellikle zengin giysi kıvrımlarıyla Helenistik Dönem üslup özellikleri yansitmaktadir.

3.9.b: (Resim 19) Yine bugün sergilendiği Roma Ulusal Müzesi'nden önce, Kardinal Ludovico Ludovisi koleksiyonunda yer aldığından bu isimle anılan 'Hermes Ludovisi' tipini de ismini koleksiyoncusundan alan eser grubu içerisinde değerlendirmek mümkündür. 
Klasik Dönem Hermes tiplerinin ilki olarak kabul edilen ve Phidias'a atfedilen orijinal bir eserin kopyası olan, iyi korunagelmiş Hermes Ludovisi (Fuchs, 1969, s. 80; LIMC, 1990, s. 364) tipinde tanrı; genç, sakalsız ve çıplak betimlenmiştir. Bugün Roma Ulusal Müzesi’nde bulunan eser, daha önce ünlü Ludovisi Koleksiyonu'nda yer aldığı için bu isimle anılmaktadır. Sol elinde caduceus (=kerykeionun Latince karşılığ 1 ) tutan Hermes, bu tipin en belirgin özelliği olarak să̆ eliyle ruhların yol göstericisi Hermes Psykhomphos sıfatını anımsatırcasına bir şeyi ya da bir yeri işaret etmektedir. Başında kanatlı şapkasıyla izlenen Hermes betiminde sağ bacak dizden hafif kırılarak yana doğru açıldığı için vücut ağırlığı genel olarak sol bacak tarafından taşınmaktadır. Bu hareketten dolayı yukarı taşan kasık çizgisi gövdenin sol tarafını sağa göre daha kısa göstermektedir.

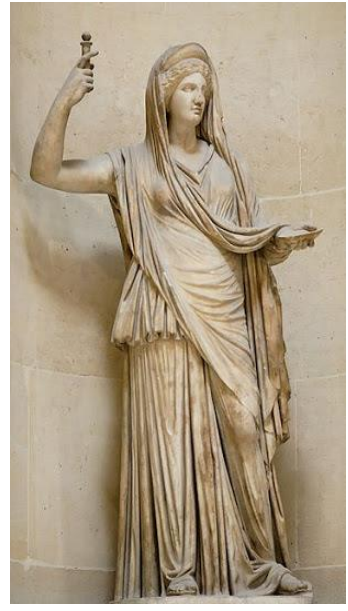

Resim 18. Hera Campana Paris Louvre Müzesi Mal: Mermer / Yük: $2 \mathrm{~m}$. (https://www.magnoliabox.com/)

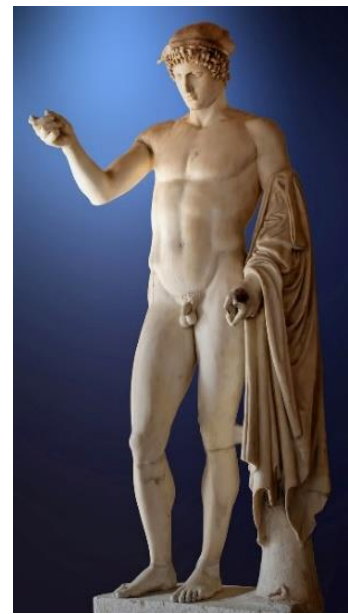

Resim 19. Hermes Ludovisi Roma Therme Müzesi

Mal: Mermer / Yük: 1.83 m. (https://tr.pinterest.com/)

3.10. Eserin Restorasyon ya da Çizimini Yapanın İsmiyle Adlandırılması: Tipleri isimlendirmemizde ve sınıflandırmamızda diğer nedenler kadar çok görülmese de heykelin restorasyonunu hatta çizimini yapan kişilerin de etkin rol oynadıkları eserler mevcuttur.

3.10.a: (Resim 20) Ayakta dinlenir vaziyette oluşturulmuş Herakles tipleri içerisinde yaygın görülen 'Lenbach Herakles'ini bu özellikte değerlendirmek doğru olacaktır. Şöyle ki; tipin orijinalini saptamak için üzerinde fazlaca çalışılan Münih Glyptothek Müzesi'nde bulunan bir 
Herakles başını 1900 yılında Furtwöngler tanımlarken daha önce bu eserin çizimlerini yapan Franz Von Lenbach adlı ressamın çalışmalarını referans kabul etmiştir (Palagia, 1990, s. 51-70). Herakles Lenbach heykelinin baş1 da, üzerinde çalışlan eserle büyük benzerlik gösterdiğinden, tip bu isimle anılmaktadır. Orijinali MÖ 320 civarına tarihlendirilen (Boardman, 1995, s. 96) eserin yaldızlı bronz kopyası Roma Conservatori Müzesi'nde sergilenmektedir. Roma Dönemi'nde Herakles'in farklı malzemeler üzerinde işlenmiş benzer örneklerine rastlanır (Metin, 2016, s. 1136-1143).

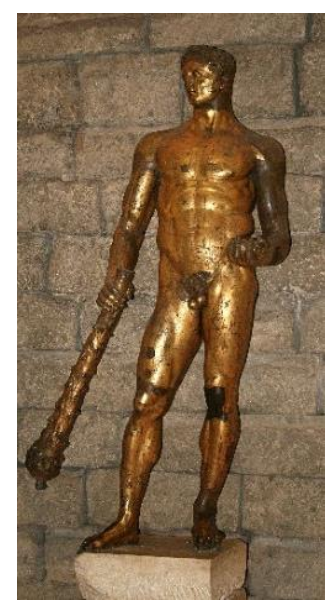

Resim 20. Lenbach Herakles'i

Roma Conservatori Müzesi

Mal: Yaldızlı Bronz / Yük: $2.41 \mathrm{~m}$.

(https://commons.wikimedia.org/)

\section{DEĞERLENDIRME VE SONUÇ:}

Antik Çağ heykeltıraşlı̆̆ı başlığı altındaki kısımda yararlanılan "Grek Heykeltıraşlığında Heykel Tipleri” konulu doktora tezimizde, metin içerisinde ara ara geçse de konu bütünlügünü dağıtmamak adına tam bir başlık altında değerlendirilmeyen heykel tiplerinin oluşumu konusu, bu makaleyi büyük oranda farklı kılarken, Grek heykeltıraşlığına değişik bir perspektifle yaklaşma olanağı da sağlamıştır.

Oluşturuldukları dönemden bu güne uzun bir zaman geçmiş olmasına rağmen hala görenleri kendine hayran bırakan Antik Çă̆ heykeltıraşl1k eserleri, elbette ki ne tezimizde gösterilenlerle ne de bu makalede örnek verilenlerle sınırlıdır. Yapıldıkları dönemlere ve toplumlara 
1ş1k tutan, sanat özellikleriyle sosyo-kültürel bağlamda ulvi bilgiler barındıran, çalışma kapsamına sığdırılamamış daha binlerce kıymetli eser bulunmaktadır. Yine de -örnekler çok sayıda olsa da- makalede her başlık için verilen iki örnek farklı tanrı-tanrıça ve mitolojik unsurdan tercih edilmeye çalışılmıştır. Bundaki en temel hedef; kısa kısa da olsa daha çok figür hakkında değerlendirme yapmak ve o figür hakkında tanımlama sunmaktır. İncelemeye tabi tutulan tiplere isim veren hususlar dışında 'Yılanlı Tanrıça' örneğinde olduğu gibi tuttukları nesnelerle, 'Şarap Tulumlu Satyr' eserinden hareketle yanlarında bulunan objelerle, 'Thermeli Yönetici' gibi meslek ve uğraşlarıyla, 'Yaralı Savaşçı'daki (Protesilaos) gibi komposizyon dâhili görünümlerinden dolayı adlandırılmış ve bu şekilde literatüre geçmiş eserler de bulunmaktadır.

Arkeolojik buluntular içerisinde önemli ve haklı bir konuma sahip olan heykeltıraşlık eserleri, engin bir derya olan bilim dünyasında konuya ilgili herkese 1ş1k saçmaya devam edecektir.

\section{KAYNAKLAR}

Alscher, L. (1961). Griechische plastik -archaik und die wandlung zur Klassik-, Berlin: Veb Deutscher Verlag Der Wissenschaften.

Başaran, C. \& Kasapoğlu, H. (2018). Kanon: Grek klasik heykeltıraşlığında estetik arayış1. Atatürk Üniversitesi Sosyal Bilimler Enstitüsü Dergisi 22, (Aralık Özel Sayı), 2835-2853.

Benucci, M. \& Sarti, S. (2001). The Campana Museum of ancient marbles in Nineteenth-century photographs. Journal of the History Collections Sayl: $24 / 1,15-24$.

Bieber, M. (1955). The sculpture of the Hellenistic age, New York: Columbia University Press.

Biers, R. W. (1987). The archaeology of Greece -an introduction-, Ithaca and London: Cornell University Press.

Blümel, C. (1957). Phidiasische reliefs und partheneonfries, Berlin: Akademie Verlag.

Boardman, J. (1967). Pre-classical -from Crete to archaic Greece-, London: Penguin Books.

Boardman, J. (1995). Yunan heykeli geç klasik dönem, Müjde Peker (Çev.). İstanbul: Homer Kitabevi.

Boardman, J. (2001). Yunan heykeli arkaik dönem, Yaşar Ersoy (Çev.). İstanbul: Homer Kitabevi.

Boardman, J. (2013). Yunan heykeli klasik dönem, Gürkan Ergin (Çev.). İstanbul: Homer Kitabevi.

Boardman, J. (2017). Yunan sanatt, Yasemin İlseven (Çev.). İstanbul: Homer Kitabevi.

Bol, C. P. (1981). Ancient art -guide to the collection-, Susan Walker (Çev.). Frankfurt am Main: Dezernat Kultur und Freizeit der Stadt. 
Charbonneaux, J. (1943). La sculpture Grecque classique II, Paris: Broché Jaquette.

Cook, R. M. (1972). Greek art its development, character and influence, London: The Trinity Press.

Fabricius, J. (1999). Die Hellenistischen totenmahlreliefs, München: Verlag Dr. Friedrich Pfeil.

Fuchs, W. (1969). Die skulptur der Griechen, München: Hirmer Verlag.

Gombrich, Ernst H. (1999). Sanatın öyküsü, Erol Erduran-Ömer Erduran (Çev.). İstanbul: Remzi Kitabevi.

Havelock, C. M. (1964). Archaistic reliefs of the Hellenistic period. American Journal of Archaeology, Sayl: 68/1, 43-58.

Havelock, C. M. (1995). The Aphrodite of Knidos and her successors -A historical review of the female nude in Greek art- Michigan: The University of Michigan Press.

Karaosmanoğlu, M. (2005). Mitoloji ve Ege'nin tanrlarl, Erzurum: Eser Ofset Matbaacilık.

Kousser, M. R. (2008). Hellenistic and Roman ideal sculpture -The allure of the classical, USA: Cambridge University Press.

LIMC (1981). Lexicon Iconographicum Mythologiae Classicae I. 1-2, "AARAAPHLAD", Zürich: Artemis Winkler Verlag.

LIMC (1984). Lexicon Iconographicum Mythologiae Classicae II. 1-2, “APHRODISIAS-ATHENA”, Zürich: Artemis Winkler Verlag.

LIMC (1988). Lexicon Iconographicum Mythologiae Classicae IV. 1-2, "EROSHERAKLES", Zürich: Artemis Winkler Verlag.

LIMC (1990). Lexicon Iconographicum Mythologiae Classicae V. 1-2, "HERAKLES-KENCHRIAS", Zürich: Artemis Winkler Verlag.

LIMC (1997). Lexicon Iconographicum Mythologiae Classicae VIII. 1-2, “THESPIADES-ZODIACUS", Zürich:,Artemis Winkler Verlag.

Lullies, R. (1956). Griechische plastik von den anfangen bis zum ausgang des Hellenismus, München: Hirmer Verlag München.

Mark, I. (1998). The victory of Samothrace. Oxbow Mongraph, Sayl: 90, 157-165.

Metin, H. (2013). An example of the transfer of the decorations on the Hellenistic mouldmade bowls to lamps: A lamp from Boubon. Colloquium Anatolicum XII, 239-252.

Metin, H. (2016). Pisidia'dan kurşun bir Herakles heykelciği üzerine bazı gözlemler. Uluslararası Sosyal Araştırmalar Dergisi, Cilt: 9 Sayl: 43, 1136-1143.

Özgan, R. (2013). Roma portre sanatı I, İstanbul: Ege Yayınları.

Palagia, O. (1990). Two statues of Hercules in the forum Boarium in Rome. Oxford Journal of Archaeology Sayl: 9/1, 51-70.

Pollitt, J. J. (1990). Art in the Hellenistic age, Cambridge, London: Cambridge University Press.

Richter, M. A. G. (1961). The archaic gravestones of Attica, London: The Phaidon Press.

Richter, M. A. G. (1970). The sculpture and sculptors of the Greeks, New Haven: Yale University Press. 
Richter, M. A. G. (1984). Yunan sanatı, Beral Madra (Çev.). (Orijinali 1959'da yayımlanmıştır), İstanbul: Cem Yayınevi

Ridgway, B S. (1970). The severe style in Greek sculpture, Princeton-New Jersey: Princeton University Press.

Ridgway, B. S. (1990). Hellenistic sculpture I, The Styles of ca. 331-200 B. C., Wisconsin: The University of Wisconsin Press.

Ridgway, B. S. (2000). Hellenistic sculpture II, London: The University of Wisconsin Press.

Ridgway, B. S. (2006). The boy strangling the goose: Genre figure or mythological symbol?. American Journal of Archaeology Sayı:110,

Rumpf, A. (1949). Yunan ve Roma sanatı, Jale İnan (Çev.). İstanbul: Pulhan Matbaasi.

Sarti, S. (2012). The Campana collection, -at the Royal Museum of art and history-, Brüxelles: Editions de Boccard.

Smith, R.R. Roland. (2013). Hellenistik heykel, Ayşin Yoltar Yıldırım (Çev.). İstanbul: Homer Kitabevi.

Stewart, A. (1990). Greek sculpture, London: Yale University Press.

Stewart, A. (2014). Art in the Hellenistic world -an introduction-, New York: Cambridge University Press.

Tavukçu, A. Y. (1999). Troas bölgesi terrakotta figürinleri, (Yayımlanmamış Doktora Tezi), Atatürk Üniversitesi Sosyal Bilimler Enstitüsü Arkeoloji Anabilim Dal, Erzurum.

Çatışma beyanı: Makalenin yazarı bu çalışma ile ilgili taraf olabilecek herhangi bir kişi ya da finansal ilişkileri bulunmadığını dolayısıyla herhangi bir çıkar çatışmasının olmadığını beyan eder.

Destek ve teşekkür: Çalışmada herhangi bir kurum ya da kuruluştan destek alınmamıştır. 